\section{Selvtillid, selvrespekt og}

selvvardsattelse

Axel Honneth: Kamp om anerkendelse

- sociale konflikters moralske grammatik.

Hans Reitzels Forlag, 2006, 246 sider, kr. 298,-

Når Honneth i Kamp om anerkendelse - sociale konflikters moralske grammatik udfolder en kritisk samfundsteori, er anknytningspunktet ikke de atomistiske samfundsteorier, hvori samfundets kampe betragtes som magtkampe drevet af individuelle særinteresser, således som de udformes i traditionen fra Machiavelli og Hobbes. Hos Honneth er det derimod den intersubjektivitetsteoretiske nyfortolkning af naturtilstandsteorien, således som den genfindes i Hegels tidlige Jena-skrifter, der er udgangspunktet. I forlængelse af Hegel fremføres det, at kampe om anerkendelse ikke skal betragtes som kampe om selvopretholdelse, men derimod som kampe om at etablere gensidige anerkendelsesrelationer. Dermed erstatter Honneth den atomistiske grundpræmis med en slags (antropologisk) naturgrundlag for den menneskelige socialisering. Når kampen om anerkendelse anses for at være af antropologisk karakter, er det ud fra en grundantagelse om, at individet ikke kan udvikle sin personlige identitet uden anerkendelse.

Om end Honneth i formuleringen af $\sin$ anerkendelsesteori inddrager Hegel, anfører Honneth i rekonstruktionen af Hegels Jena-skrifter og den heri fremsatte anerkendelsesteori, at denne teori hviler på et abstrakt grundlag og derfor må gentænkes. Derfor poder Honneth Hegels anerkendelsesteori med George Herbert Meads socialpsykologi, hvorved teorien får en mere materialistisk drejning.

Ambitionen med Honneths kritiske samfundsteori er at konstruere et formelt begreb for sædeligheden, der udgør de formelle betingelser for menneskets selvrealisering. Idéhistorisk betragtet er det formelle begreb for sædeligheden konstrueret som en sammentænkning af tankegods fra både Kants universalistiske deontologi og Aristoteles' partikularistiske og eudamonistiske betragtninger over 'det gode liv'. Honneth fokuserer således ikke på udformningen af det specifikke indhold i det enkelte gode liv, men derimod på de formelle betingelser, der må være til stede for individets selvrealisering. Argumentationen for det formelle begreb om sædeligheden er ikke metafysisk men derimod det, som Honneth betegner som en metodologisk begrundelsesstrategi. Det betyder, at de formelle betingelser, der er uforanderlige konstanter, begrundes ud fra allerede eksisterende og observerbare fænomener. Med anvendelsen af en metodologisk begrundelsesstrategi demonstrerer Honneth, hvorledes der ud af et etisk-deskriptivt niveau springer en række normative anerkendelsesfordringer. Det er i særdeleshed med hensyn til anvendelsen af denne begrundelsesstrategi, at 
Honneth afslører sit tilhørsforhold til Frankfurterskolen - ikke mindst som den kommer til udtryk hos læremesteren Habermas.

Om anerkendelsesfordringerne gæelder det, at de knytter sig til tre differentierede former for anerkendelse, der tillige er knyttet til tre forskellige anerkendelsessfærer. Én anerkendelsessfære er kærlighedens sfære, der adskiller sig fra de øvrige derved, at den udgør forudsætningen for overhovedet at kunne indgå $i$ intersubjektive forhold. Kærlighed og venskab udgør den emotionelle anerkendelse, der sætter subjektet i stand til at respektere sig selv som én, der kan indgå $i$ både fællesskabets og samfundets forhold.

Anerkendelsen af subjektets evne til at foretage autonome moralske handlinger udgør en anden anerkendelsesform. I det borgerlige samfund tildeles mennesket i kraft af sin menneskelighed universelle rettigheder, og netop som indehaver af sådanne rettigheder vinder det enkelte menneske selvrespekt ved at kunne betragte sig selv som et moralsk individ. I modsætning til kærlighedens mere private og emotionelle anerkendelsesform, er dette en kognitiv anerkendelsesform.

I den tredje anerkendelsessfære værdsættes individets evne til deltagelse og engagement. I denne sfære anerkendes individet for sin medvirken til samfundets og fællesskabets reproduktion. Det er netop værdsættelsen af sig selv som medlem af et solidarisk fællesskab, der er omdrejningspunktet for denne tredje type af anerkendelse. Anerkendelsen i denne sfære er både en emotionel og kognitiv anerkendelse, idet solidariteten både omfatter regulering af mellemmenneskelige relationer og skabelsen af identifikation og samhørighed.

Anerkendelsens sfærer er samfundsmæssigt integrerende og gensidigt betingende, således at kærlighed er en afgørende forudsætning for følelsen af sikkerhed, men tillige for individets møde med samfundet.

Når anerkendelse gøres til omdrejningspunkt for en teori om samfundet, bliver det interessant at undersøge hvad der sker, når anerkendelsen er fraværende. Udebliver anerkendelsen og dermed den følelsesmæssige opmærksomhed, den kognitive respekt eller den sociale agtelse, mister individet ifølge Honneth sit positive selvforhold. Individet gør sig ved anerkendelsens fravær en række ringeagtserfaringer, der ifølge Honneth korresponderer med de respektive anerkendelsesformer. Det betyder med andre ord, at et overgreb kan aflæses som et fravær af en grundlæggende selvtillid hos individet. Ligeledes korresponderer fratagelsen af rettigheder som et fravær af selvrespekt, og endelig kan manglen på social agtelse $\mathrm{i}$ forskellige former for nedværdigelse aflæses som en grundlæggende mangel på selvvardsattelse.

Anerkendelseskampe kan ifølge Honneth udfolde sig på to måder. Enten udspiller de sig i det offentlige 
rum, hvor de - foranlediget af krænkelser eller uindfriede forventninger via eksempelvis politiske beslutningsprocesser - indløser de anerkendelsesfordringer som er tilstede $\mathrm{i}$ de enkelte anerkendelsessfærer. Eller også udfolder de sig hinsides den offentlige sfære, hvor de udformer sig som alternative anerkendelsesfællesskaber. Om end de sidstnævnte anerkendelsesfællesskaber ofte tilbyder mere eller mindre perverse erstatningsoplevelser af samhørighed, udgør de centrale udfordringer for den demokratiske kultur. På den ene side udgør disse subkulturer ofte en trussel for den demokratiske kultur, idet subkulturerne ofte er ekstremistisk forankrede. På den anden side udgør modstandskulturerne et demokratisk korrektiv, idet de bestandigt udfordrer definitionen af, hvad der kan opnå anerkendelse.

Med udgivelsen af Kamp om anerkendelse - sociale konflikters moralske grammatik foreligger et af det 20. århundredes politisk- og socialfilosofiske hovedværker $i$ en gennemarbejdet dansk oversættelse af Arne Jørgensen.

Morten Sorensen

Gud efter Grosboll \& Granser for Gud.

Henrik Brandt-Pedersen og Hans Hauge (red.): Gud efter Grosboll - Religion og samfund. Anis, 2005, 184 sider, kr. 218 ,-
Michael Jarlner og Anders Jerichow: Granser for Gud - Giv det verdslige samfund en chance. Gyldendal, 2005, 183 sider, kr. 168,-

Artikelsamlingen Gud efter Grosboll - Religion og samfund består af fem redigerede forelæsninger fra forelæsningsrækken Gud efter Grosboll: Tro og viden ved Folkeuniversitetet $\mathrm{i}$ Århus og derefter i Odense, suppleret med en artikel af Ole Jensen. At Grosbøll-sagen blev forelæsningsrækkens anledning har ikke betydet, at bogen alene forholder sig snævert hertil, tværtimod rækker den langt ud over selve sagen. De første tre artiklers fokus ligger på Thorkild Grosbølls egne ytringer, som de kommer til udtryk i bogen En sten $i$ skoen (2003). De tre sidste er af mere perspektiverende karakter; omdrejningspunktet er diskussionen om forholdet mellem religion og samfund, samt om forholdet mellem viden og tro. Som helhed understreger artikelsamlingen således, at Grosbøll-sagen rummer andet og mere end kirkelige og teologiske diskussioner.

Hans Hauge indleder bogen med en række polemiske nedslag i Grosbølls værk. Det er en myte, at Grossbøll vil udskifte et gammeldags, teistisk gudsbegreb med et tidssvarende gudsbillede. Da Gud hos Grosbøll har abdiceret $\mathrm{i}$ Jesus, i næsten, er der ganske enkelt ikke noget at lave et gudsbillede af? Hauge betoner det problematiske i, at Grosbøll insisterer på en kristendom uden nogen form for 